\title{
DEVELOPING NEW METHODS OF SPINAL CORD INJURY TREATMENT USING MAGNETIC NANOPARTICLES IN COMBINATION WITH ELECTROMAGNETIC FIELD
}

\author{
DESENVOLVIMENTO DE NOVOS MÉTODOS DE TRATAMENTO DE LESÕES MEDULARES \\ QUE USAM NANOPARTÍCULAS MAGNÉTICAS EM COMBINAÇÃO COM CAMPOS \\ ELETROMAGNETICOS
}

\author{
DESARROLLO DE NUEVOS MÉTODOS DE TRATAMIENTO DE LESIONES MEDULARES \\ QUE USAN NANOPARTÍCULAS MAGNÉTICAS EN COMBINACIÓN CON CAMPOS \\ ELECTROMAGNÉTICOS
}

Sergey Kolesov', Andrey Panteleyev', Maxim Sazhnev', Arkadiy Kazmin

1. N.N. Priorov Federal Scientific Research Institute of Traumatology and Orthopedics, 10 Priorov Street, 127299, Moscow, Russia.

\begin{abstract}
Objective: To determine the amount of loss of function after spinal cord transection of varying extents, and whether magnetic iron oxide nanoparticles, in combination with an external magnetic field, improve the rate of subsequent functional recovery in rats. Methods: The animals were divided into groups with 50\%, $80 \%$ and complete spinal cord transection. The animals of all three study groups were administered magnetic iron oxide nanoparticle suspension to the area of injury. The three control groups were not administered magnetic nanoparticles, but had corresponding transection levels. All animals were exposed to a magnetic field for 4 weeks. Loss of postoperative function and subsequent recovery were assessed using the BBB motor function scale and somatosensory evoked potential monitoring on the first day after surgery, and then weekly. Terminal histological analysis was also conducted in all the groups. Results: The animals in the control or complete transection groups did not demonstrate statistically significant improvement in either the BBB scores or evoked potential amplitude over the four-week period. In the group with 50\% transection, however, a statistically significant increase in evoked potential amplitude and BBB scores was observed four weeks after surgery, with the highest increase during the second week of the study. In the group with $80 \%$ transection, only improvement in evoked potential amplitude was statistically significant, although less pronounced than in the $50 \%$ transection group. Conclusion: The use of magnetic iron oxide nanoparticles in combination with a magnetic field leads to higher rates of functional recovery after spinal cord injury in laboratory animals. The mechanism of this functional improvement needs further investigation.
\end{abstract}

Keywords: Spinal cord injuries; Magnetite nanoparticles; Magnetic field therapy; Rats, Wistar.

RESUMO

Objetivo: Determinar a quantidade de perda de função depois de transecção de medula espinal de várias extensões, e se as nanopartículas magnéticas de óxido de ferro combinadas a um campo magnético externo melhoram a taxa de recuperação funcional em ratos. Métodos: Os animais foram divididos em grupos com transecção de medula espinal de 50\%, 80\% e completa. Os animais dos três grupos do estudo receberam suspensão de nanopartículas magnéticas de óxido de ferro na região da lesão. Os três grupos controle não receberam as nanopartículas magnéticas, mas tinhas níveis de transecção correspondentes. Todos os animais foram expostos a um campo magnético durante 4 semanas. A perda de função pós-operatória e a recuperação subsequente foram avaliadas pela escala de BBB quanto à função motora e por monitoração do potencial somatossensorial evocado no primeiro dia depois da cirurgia e, a seguir, uma vez por semana. A análise histológica terminal também foi realizada em todos os grupos. Resultados: Os animais do grupo controle ou nos grupos transecção completa não demonstraram melhora estatisticamente significante tanto nos escores BBB quanto na amplitude do potencial evocado durante o período de quatro semanas. No grupo com transecção de 50\%, porém, constatou-se um aumento estatisticamente significante da amplitude do potencial evocado e dos escores BBB quatro semanas depois da cirurgia, sendo o maior aumento durante a segunda semana do estudo. No grupo com transecção de $80 \%$, só a melhora da amplitude do potencial evocado teve significância estatística, embora inferior à verificada no grupo com transeção de 50\%. Conclusões: O uso de nanopartículas magnéticas de óxido de ferro combinadas com um campo magnético, leva a taxas mais altas de recuperação funcional depois de lesão da medula espinal em animais de laboratório. O mecanismo dessa melhora precisa ser mais investigado.

Descritores: Traumatismos da medula espinal; Nanopartículas de magnetita; Terapia de campo magnético; Ratos Wistar.

\section{RESUMEN}

Objetivo: Determinar la cantidad de pérdida de función después de transección de médula espinal de varias extensiones, y si las nanopartículas magnéticas de óxido de hierro combinadas a un campo magnético externo mejoran la tasa de recuperación funcional en ratas. Métodos: Los animales fueron divididos en grupos con transección de médula espinal de 50\%, 80\% y completa. Los animales de los tres grupos del estudio recibieron suspensión de nanopartículas magnéticas de óxido de hierro en la región de la lesión. Los tres grupos control 
no recibieron las nanopartículas magnéticas, pero tenían niveles de transección correspondientes. Todos los animales fueron expuestos a un campo magnético durante 4 semanas. La pérdida de función postoperatoria y la recuperación subsiguiente fueron evaluadas por la escala de BBB cuanto a la función motriz u por monitorización del potencial somatosensorial evocado en el primer día después de la cirugía y, a continuación, una vez por semana. El análisis histológico terminal también fue realizado en todos los grupos. Resultados: Los animales del grupo control o en los grupos transección completa no demostraron mejora estadísticamente significativa tanto en los escores BBB como en la amplitud del potencial evocado durante el período de cuatro semanas. En el grupo con transección de 50\%, sin embargo, se constató un aumento estadísticamente significativo de la amplitud del potencial evocado y de los escores BBB cuatro semanas después de la cirugía, siendo el mayor aumento durante la segunda semana del estudio. En el grupo con transección de 80\%, sólo la mejora de la amplitud del potencial evocado tuvo significancia estadística, aunque inferior a la verificada en el grupo con transección de 50\%. Conclusiones: El uso de nanopartículas magnéticas de óxido de hierro combinadas con un campo magnético, lleva a tasas más altas de recuperación funcional después de lesión de la médula espinal en animales de laboratorio. El mecanismo de esa mejora precisa ser más investigado.

Descriptores: Traumatismos de la médula espinal; Nanopartículas de magnetita; Terapia de campo magnético; Ratas Wistar.

\section{INTRODUCTION}

Spinal cord injury (SCl) is currently one of the most serious medical problems with no effective clinical solution. It affects up to 2.5 million people worldwide, with almost 130,000 injuries a year. ${ }^{1}$ In most cases, SCl leads to severe disability, including loss of motor and sensory function, and loss of bladder, bowel and respiratory function, depending on the level of the injury. Despite considerable progress in patient care and rehabilitation techniques, the need to develop neuroregenerative strategies for patients with $\mathrm{SCl}$ is indisputable.

Contrary to the peripheral nervous system, the capacity of the neural cells in adult mammalian CNS to regenerate is extremely limited. Substantial axonal regrowth in the spinal cord is only possible in the early stages of development., ${ }^{2,3}$ At later stages in life, however, the extension of axons across the injury site in the central nervous system is impeded by the formation of a glial scar that stabilizes the integrity of the damaged tissues, preventing further inflammation and possible infection. However, this process creates an insurmountable barrier for the regenerating axons, preventing the extension of their growth cones, both physically and chemically. ${ }^{4,5}$ In recent years, vast amounts of experimental research have been conducted, aimed at elucidating and stimulating the mechanisms of CNS tissue regeneration, with most efforts concentrating on cellular and molecular therapeutic interventions. ${ }^{6-14}$ However, it is widely accepted that besides biochemical cues, the process of growth cone elongation is also influenced by tensile forces. Recently, mechanical stimulation of axonal growth has been examined, as a novel way of inducing neural regeneration. ${ }^{15-18}$ The use of magnetic nanoparticles to restore loss of function related to spinal cord injury represents a promising approach to this challenge, as it allows spatial modulation of the axonal elongation process, without inducing further damage to the injured CNS tissue.

Magnetic nanoparticles have been widely used in experimental research for magnetic imaging, targeted delivery, bioengineering, cell culture cultivation, and other applications. ${ }^{19-23}$ Their small size, high biocompatibility, readily available protocols of surface functionalization with various biological molecules and, most importantly, the ability to interact with magnetic field forces, meet the requirements needed for potential mechanical stimulation of axonal growth.

The current experimental study aims to determine the effectiveness of magnetic iron oxide nanoparticles in functional recovery from SCl through potential stimulation of in vivo axon growth and elongation in the presence of an external magnetic force.

\section{METHODS}

This research was approved by the N.N. Priorov Central Institute of Traumatology and Orthopedics Ethics Committee (\#12548977).

Experimental design

The study was conducted on 72 healthy adult (8-10 weeks) female Wistar rats, weighing $220-310 \mathrm{~g}$, which were kept at $23^{\circ} \mathrm{C}$ on a regular $12 \mathrm{~h}$ light/dark cycle with a carefully maintained diet. The animals were divided into 6 groups, according to the extent of spinal cord transection. The rats underwent a 50\% spinal cord transection in the first study group, an $80 \%$ transection in the second group, and a complete transection in the third study group. All the animals in the three study groups were administered a magnetic iron oxide nanoparticle $\left(\mathrm{Fe}_{3} \mathrm{O}_{4}, 10-50 \mathrm{~nm}\right.$ in diameter) suspension to the area of injury, through a polyethylene catheter, every other day for 4 weeks. The other three groups were control groups, with no magnetic nanoparticles administered but with corresponding transection levels. All the animals were exposed to a static direct current $3 \mathrm{mT}$ magnetic field for 5 hours, every other day, for 4 weeks.

\section{Surgical procedures}

All the surgeries were conducted by the same surgeons, using a surgical microscope, under strict aseptic conditions, maintaining the animals' body temperature at $38^{\circ} \mathrm{C}$. The animals were anesthetized intraperitoneally using xylazine $(10 \mathrm{mg} / \mathrm{kg})$ and ketamine $(100 \mathrm{mg} /$ $\mathrm{kg}$ ). Additional doses were administered intraoperatively, as needed.

The thoracic area was shaved and cleaned with iodine solution and $70 \%$ alcohol. After a $4 \mathrm{~cm}$ midline incision and paraspinal muscle separation, a laminectomy was performed at the T9/T10 level using microsurgical rongeurs to expose the spinal cord. The spinal cord was transected (50\%, $80 \%$ and complete transection) with a $0.1 \mathrm{~mm}$ blade using a custom-made guard, taking care to cause minimal damage to the surrounding arteries. After confirming the transection, the muscles and skin were closed in layers. After surgery, $5 \mathrm{~mL}$ of D5 lactated Ringer's solution was injected intraperitoneally to prevent dehydration, and the animals were kept on a heating pad to maintain body temperature for two hours. During the first three days following surgery, all the animals were injected with gentamicin-cefazolin $20 \mathrm{mg} /$ $\mathrm{kg}$ to prevent infection, and food and water were provided ad libitum. If spontaneous urination was not observed, the urinary bladder was manually evacuated two times a day.

\section{Behavioral and electrophysiological assessment}

Spontaneous function of the hind limbs was evaluated on the first day after surgery and then weekly for 4 weeks. The scoring was done by blinded independent observers using the BBB (Basso, Beattie, and Bresnahan) motor function scale. ${ }^{24}$ The BBB scale allows for quantitative analysis of sensorimotor function after $\mathrm{SCl}$, and ranges from zero (no movement) to 21 (normal gait with full coordination) points. The scoring is based on the assessment of joint movement, paw placement and gait stability. Scores ranging from 0 to 7 points mainly describe the movements in the large joints of the hind limbs, scores of 8 to 13 describe coordination and paw placement, and scores of 14 and higher describe overall stability of the gait.

Electrophysiological evaluation of the functional integrity of the descending tracts of the spinal cord was conducted before surgery to determine the baseline values, then on the first day after surgery, and weekly for 4 weeks thereafter. The animals were anesthetized (with xylazine and ketamine, as described above) and evaluated using compound motor evoked potential (MEP) testing. ${ }^{25}$ The potentials were recorded from the tibialis anterior muscles of the hind limbs after transcranial stimulation of the brain cortex using bipolar needle electrodes. The duration of the stimulus was $0.2 \mathrm{~ms}$ and its intensity was $10 \mathrm{~mA}$ at $10 \mathrm{~Hz}$. A minimum of three MEP traces were recorded over a $25 \mathrm{~ms}$ duration. The recorded traces were amplified and digitized. The amplitude was measured in $\mu \mathrm{V}$. 


\section{Histological analysis}

After four weeks, the animals were deeply anesthetized by intraperitoneal injection of ketamine $(70 \mathrm{mg} / \mathrm{kg})$ and perfused transcardially with cold saline solution followed by $4 \%$ paraformaldehyde in phosphate-buffered saline $0.1 \mathrm{M}$. The vertebral column was extracted from T7 to L3 and post-fixed according to the standard protocol. A spinal cord tissue block that included the region of transection was then cryosectioned, stained (H\&E, Masson's trichrome), and mounted on a slide. The stained spinal cord lesion sites were then analyzed under a microscope (Nikon Corporation, Japan) using image analysis software.

\section{Statistical analysis}

Statistical analysis was performed using Statistical Package for Social Sciences version 18 software (SPSS Inc, Chicago, IL, USA). Data comparison between the groups was performed for each weekly time point using the Kruskal-Wallis test, with post hoc analysis using the Mann-Whitney $U$ test. All results were expressed as means \pm standard error of the mean (SEM). The criterion level for statistical significance was set at a $P$ value of less than 0.05 .

\section{RESULTS}

\section{Postsurgical survival rate}

The survival rate after spinal cord transection was 85\% (61 out of 72 animals) on the day after surgery. By the end of the first week, 51 animals $(71 \%)$ survived, and remained in the experiment for the remainder of the four weeks. Animals with complete spinal cord transection were less likely to survive, which was most likely due to self-mutilation and urinary bladder rupture or urinary tract infection. The final data was collected for the following number of animals in each group: 50\% transection + MNP - 10 (out of 12); $80 \%+$ MNP -11 (out of 12 ); $100 \%$ transection + MNP - 7 (out of 12); $50 \%$ control -9 (out of 12 ); $80 \%$ control - 8 (out of 12); $100 \%$ control - 6 (out of 12).

\section{Behavioral assessment results}

As expected, the animals in all the groups showed a drastic decrease in function on the first day after surgery, with no or minimal voluntary movement observed in the hind limbs. On the first day after transection, the BBB scores decreased from an average of $21.0 \pm 0$ points at the pre-injury baseline to an average of $1.1 \pm 0.8$ points. There were no statistically significant functional differences between groups on the first day after surgery. One week after surgery, the animals in the control groups did not demonstrate statistically significant improvement in BBB scores or evoked potential amplitude over the four-week period. Neither was any statistically significant improvement observed in the study group with complete spinal cord transection. In the group with 50\% transection, however, there was an average of $4.3 \pm 1.4$ point increase $(p<0.001)$ in BBB scores four weeks after surgery, with slight or extensive movement in two or more joints in the hind limbs, albeit with no or very little weight bearing. In the group with $80 \%$ spinal cord transection, the average increase after 4 weeks was $2.3 \pm 1.7$ points $(p=0.061)$, which was close to the statistical significance threshold. The BBB scores increased gradually over the four-week period, with the most marked improvement being observed during the second week of the study. (Figure 1)

\section{Electrophysiological assessment results}

As with the functional scores, on the first day after surgery, the average amplitudes of the evoked potentials demonstrated a drastic decrease in all groups, with failure to register any potentials in some animals. The differences in amplitude between groups on the first day after surgery were not statistically significant, although the average amplitudes in the 50\%-transection groups were slightly higher. On the first postoperative day, the average amplitudes constituted on average $4.7 \pm 1.4 \%$ of the preoperative amplitude values (average of $538.7 \pm 91.5 \mu \mathrm{V}$ ).

The animals in the control groups or the study group with complete spinal cord transection also did not demonstrate statistically significant increase in evoked potential amplitude over the four-week period. The group with $50 \%$ transection demonstrated gradual improvement in electrophysiological response, with the average amplitude reaching $14.1 \pm 3.5 \%(p<0.001)$ of the preoperative value by the end of the fourth week. There was also a statistically significant improvement in amplitude in the group with $80 \%$ spinal cord transection four weeks after surgery, which constituted $5.0 \pm 3.0 \%(p<0.05)$ of the original value. In both cases, the most rapid increase in amplitude was observed during the second week of the study. (Figure 2) Repeated transection of the spinal cord rostral to the original lesion site abolished the recovered hind limb movements and evoked potential improvements in both groups.

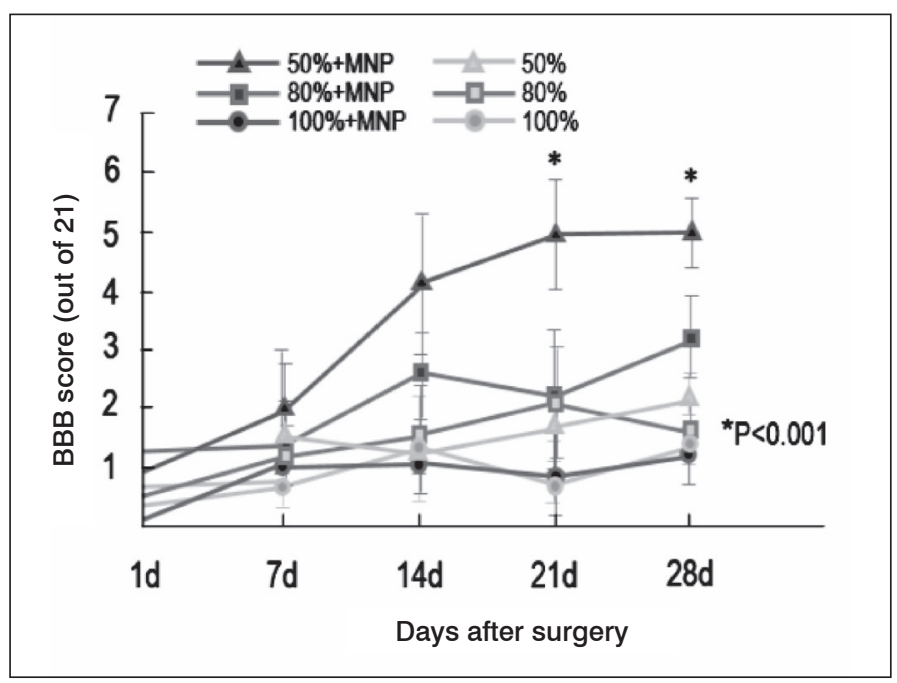

Figure 1. Comparison of the changes in BBB scores over 4 weeks. (MNP magnetic nanoparticles).

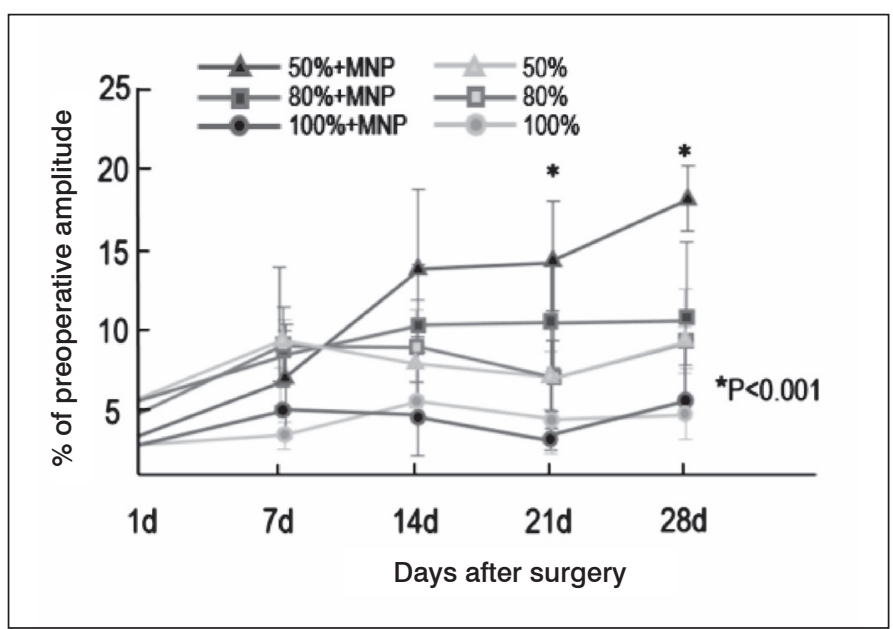

Figure 2. Comparison of the changes in evoked potential amplitudes over 4 weeks. (MNP - magnetic nanoparticles).

\section{Histopathological assessment results}

Histological analysis of the lesion sites performed 4 weeks after surgery yielded no significant differences in terms of hemorrhage, necrosis or cellular infiltration. However, the experimental groups had higher viable motor neuron counts and thicker myelinated fibers. Measurement of the cavity area showed an area that was, on average, $17.8 \pm 2.4 \%$ times smaller $(p<0.05)$ in the experimental group with $50 \%$ transection. Although Masson's trichrome staining demonstrated pronounced glial reactions in the areas next to the lesions, collagen content was significantly lower in the experimental group with $50 \%$ transection. 


\section{DISCUSSION}

The study demonstrates that the use of magnetic iron oxide nanoparticles in combination with an external magnetic field leads to higher rates of functional recovery after spinal cord injury in laboratory animals. We were able to quantitatively and objectively assess the extent of function loss and recovery after experimental spinal cord transection on a laboratory rat model, showing a statistically significant improvement in the animals that received magnetic nanoparticles locally and were exposed to a magnetic field over a 4 week period.

It is widely accepted that regeneration of the central nervous system is extremely limited. Spinal cord injury therefore leads to severe disability and permanent function loss in most cases. These changes are caused by the formation of a glial scar that acts as a physical and chemical barrier for growing axons. Our histopathological analysis has demonstrated the extensive changes involving collagenous tissue formation at the sites of transection were strongly correlated with decreased function. Although extensive research has been conducted on various molecular agents that can prevent glial scar formation, as well as cellular engineering aimed at restoring the neuronal pool at the site of the injury, mechanical modulation of the axon growth and elongation process has recently been given consideration. The main goals of this approach include directing axonal growth and stimulating their elongation across the lesion site. The combined use of magnetic iron oxide nanoparticles with a magnetic field represents a safe and noninvasive approach to this problem. Magnetic iron oxide nanoparticles have a very low cytotoxic profile and are known to accumulate intracellularly, making them highly suitable for the task. ${ }^{26,27}$

The results of this study indicate that compared to the control groups, the abovementioned combination has a positive effect on the process of neural regeneration, which has been substantiated by electrophysiological, behavioral and histological data, suggesting the formation of new neuronal connections. This fact has been further supported by the retransection of the spinal cord above the lesion site, leading to a complete loss of function.

The mechanism of the functional improvement described needs further investigation.

All authors declare no potential conflict of interest related to this article.

CONTRIBUTION OF THE AUTHORS: This manuscript describes an experimental study with contributions from four authors. Each of the authors has provided a significant input into the research and article revision. SK developed the plan of the experiment, supervised the research at every step, and revised the final copy of the article. AP was the main contributor to the drafting of the article and the statistical analysis. AP, AK and MS contributed equally to the surgical interventions, postoperative care and evoked potential and visual assessment of motor recovery of the experimental animals, as well as the literature analysis and revision of the text.

\section{REFERENCES}

1. Thuret $\mathrm{S}$, Moon LD, Gage FH. Therapeutic interventions after spinal cord injury. Nat Rev Neurosci. 2006;7(8):628-43.

2. Keirstead HS, Pataky DM, McGraw J, Steeves JD. In vivo immunological suppression of spinal cord myelin development. Brain Res Bull. 1997;44(6):727-34.

3. Nicholls J, Saunders N. Regeneration of immature mammalian spinal cord after injury. Trends Neurosci. 1996;19(6):229-34.

4. Galtrey CM, Fawcett JW. The role of chondroitin sulfate proteoglycans in regeneration and plasticity in the central nervous system. Brain Res Rev. 2007;54(1):1-18.

5. Busch SA, Silver J. The role of extracellular matrix in CNS regeneration. Curr Opin Neurobiol. 2007:17(1):120-7.

6. Plemel JR, Wee Yong V, Stirling DP. Immune modulatory therapies for spinal cord injury-past, present and future. Exp Neurol. 2014;258:91-104.

7. Gensel JC, Donnelly DJ, Popovich PG. Spinal cord injury therapies in humans: an overview of current clinical trials and their potential effects on intrinsic CNS macrophages. Expert Opin Ther Targets. 2011;15(4):505-18.

8. Tetzlaff W, Okon EB, Karimi-Abdolrezaee S, Hill CE, Sparling JS, Plemel JR, et al. A systematic review of cellular transplantation therapies for spinal cord injury. J Neurotrauma. 2011;28(8):1611-82.

9. Cadotte DW, Fehlings MG. Spinal cord injury: a systematic review of current treatment options. Clin Orthop Relat Res. 2011:469(3):732-41.

10. Gorrie CA, Hayward I, Cameron N, Kailainathan G, Nandapalan N, Sutharsan R, et al. Effects of human OEC-derived cell transplants in rodent spinal cord contusion injury. Brain Res. 2010;1337:8-20.

11. Agudo M, Woodhoo A, Webber D, Mirsky R, Jessen KR, McMahon SB. Schwann cell precursors transplanted into the injured spinal cord multiply, integrate and are permissive for axon growth. Glia. 2008;56(12):1263-70.

12. Kang KN, Lee JY, Kim DY, Lee BN, Ahn HH, Lee B, et al. Regeneration of completely transected spinal cord using scaffold of poly(D,L-lactide-co-glycolide)/small intestinal submucosa seeded with rat bone marrow stem cells. Tissue Eng Part A. 2011;17(17-18):2143-52.

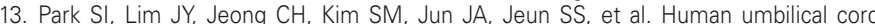
blood-derived mesenchymal stem cell therapy promotes functional recovery of contused rat spinal cord through enhancement of endogenous cell proliferation and oligogenesis. J Biomed Biotechnol. 2012;2012:362-473.
14. Franz S, Weidner N, Blesch A. Gene therapy approaches to enhancing plasticity and regeneration after spinal cord injury. Exp Neurol. 2012;235(1):62-9.

15. Suter DM, Miller KE. The emerging role of forces in axonal elongation. Prog Neurobiol. 2011;94(2):91-101.

16. Franze K. The mechanical control of nervous system development. Development. 2013:140(15):3069-77.

17. Smith $\mathrm{DH}$. Stretch growth of integrated axon tracts: extremes and exploitations. Prog Neurobiol. 2009;89(3):231-9.

18. Heidemann SR, Bray D. Tension-driven axon assembly: a possible mechanism. Front Cell Neurosci. 2015;9:316.

19. Santo VE, Rodrigues MT, Gomes ME. Contributions and future perspectives on the use of magnetic nanoparticles as diagnostic and therapeutic tools in the field of regenerative medicine. Expert Rev Mol Diagn. 2013;13(6):553-66.

20. Vaněček V, Zablotskii V, Forostyak S, Růžička J, Herynek V, Babič M, et al. Highly efficient magnetic targeting of mesenchymal stem cells in spinal cord injury. Int J Nanomedicine. 2012;7:3719-30

21. Bock N, Riminucci A, Dionigi C, Russo A, Tampieri A, Landi $E$, et al. A novel route in bone tissue engineering: magnetic biomimetic scaffolds. Acta Biomater. 2010;6(3):786-96.

22. Huang H, Delikanli S, Zeng H, Ferkey DM, Pralle A. Remote control of ion channels and neurons through magnetic-field heating of nanoparticles. Nat Nanotechnol. 2010:5(8):602-6.

23. Pankhurst QA, Connolly J, Jones SK, Dobson J: Applications of magnetic nanoparticles in biomedicine. J Phys D-Appl Phys2003;36(13): R167-81.

24. Basso DM, Beattie MS, Bresnahan JC. A sensitive and reliable locomotor rating scale for open field testing in rats. J Neurotrauma. 1995;12(1):1-21.

25. Nashmi $\mathrm{R}$, Imamura $\mathrm{H}$, Tator $\mathrm{CH}$, Fehlings MG. Serial recording of somatosensory and myoelectric motor evoked potentials: role in assessing functional recovery after graded spinal cord injury in the rat. J Neurotrauma. 1997;14(3):151-9.

26. Ito A, Shinkai M, Honda $H$, Kobayashi T. Medical application of functionalized magnetic nanoparticles. J Biosci Bioeng. 2005;100(1):1-11.

27. Pisanic TR 2nd, Blackwell JD, Shubayev VI, Fiñones RR, Jin S. Nanotoxicity of iron oxide nanoparticle internalization in growing neurons. Biomaterials. 2007;28(16):2572-81. 